\title{
The bactericidal action of streptomycin: membrane permeabilization caused by the insertion of mistranslated proteins into the cytoplasmic membrane of Escherichia coli and subsequent caging of the antibiotic inside the cells due to degradation of these proteins
}

\author{
Hans-JÜrgen Busse, $\uparrow$ Claudia Wöstmann and Evert P. BakkeR* \\ Universität Osnabrück, Fachgebiet Mikrobiologie, Postfach 4469, D-4500 Osnabrück, FRG
}

(Received 10 July 1991; revised 11 October 1991; accepted 5 November 1991)

\begin{abstract}
The mechanism by which the aminoglycoside antibiotic streptomycin permeabilizes the cytoplasmic membrane of Escherichia coli cells was reinvestigated. For this purpose, the extent of streptomycin-induced $\mathrm{K}^{+}$loss from cells growing at low external $\mathrm{K}^{+}$concentrations was taken as a measure of membrane permeabilization. Experiments with different $\mathrm{K}^{+}$-uptake mutants showed that the antibiotic specifically increased the passive permeability of the cell membrane to $\mathrm{K}^{+}$and other ions. These permeability changes were small and the membrane potential of the treated cells remained high. The membrane permeabilization was not due to a direct interaction of the antibiotic with the cell membrane, since cells that carry an rps $L$ mutation and synthesize proteins in a streptomycininsensitive way did not lose $\mathrm{K}^{+}$after the addition of the antibiotic. Due to misreading and premature termination of translation the cells synthesized aberrant proteins under the conditions where membrane permeabilization occurred. Two conditions are described under which the cells both degraded these mistranslated proteins rapidly and reaccumulated $\mathrm{K}^{+}$, lending support to the hypothesis that membrane permeabilization is due to the presence of the mistranslated proteins in the cell membrane. Evidence is presented that the irreversibility of (dihydro)streptomycin uptake by cells washed free from the antibiotic might also be due to rapid degradation of the mistranslated proteins, leading to 'caging' of the antibiotic inside the cells.
\end{abstract}

\section{Introduction}

Aminoglycoside antibiotics primarily inhibit the process of translation in prokaryotes (for reviews see Davis et al., 1974; Hancock, 1981 $a$; Davis, 1987). The molecular basis for this inhibition differs from compound to compound, and is often the consequence of a number of pleiotropic effects, such as interaction with the $16 \mathrm{~S}$ RNA, formation of an unstable initiation complex, inhibition of elongation, prevention of A-site occupation and misreading during translation (Nierhaus \& Wittmann, 1980; Brimacombe, 1988; Hausner et al., 1988; Wittmann, 1989). However, none of these effects explains why aminoglycosides are lethal to bacterial cells: the binding of streptomycin to the ribosome is

* Author for correspondence. Tel. 541 9692855; fax 5419692870.

† Present address: Institut für Mikrobiologie und Genetik, Universität Wien, Althahnstraße 14, 1090 Wien, Austria.

Abbreviations: TPMP+, triphenylmethylphosphonium cation; TPP ${ }^{+}$, tetraphenylphosphonium cation. reversible (Chang \& Flaks, 1972; Andry \& Bockrath, 1974), and one would therefore expect efflux of the antibiotic from the cells to occur after the suspension has been diluted for plating, leading to bacteriostatic rather than bactericidal effects. Hence, it has been proposed that streptomycin and other bactericidal aminoglycosides must have a second site of action, causing the lethal event (Hancock, 1981 $a, b$; Davis, 1987).

However, the uptake of dihydrostreptomycin by Escherichia coli is irreversible (Muir et al., 1984; Nichols \& Young, 1985). Davis (1987) has therefore proposed that the drug does not leave the cells during plating, leading to prolonged inhibition of protein synthesis, which prevents the formation of colonies on the plates. Apart from the fact that it is unclear why streptomycin uptake is irreversible (Nichols, 1989), this mechanism does not explain why aminoglycosides like streptomycin, gentamycin or kanamycin are bactericidal, whereas two compounds with a closely related structure, the aminocyclitols spectinomycin and kasugamycin, only exert bacteriostatic effects (Hancock, 1981 $a$; Davis, 1987). 
The difference between these two groups of compounds is that the aminoglycosides induce misreading of protein synthesis, whereas the two aminocyclitols do not (Hancock, 1981a, b; Piepersberg, 1985; Davis et al., 1986; Bakker, 1992).

Hancock $(1981 b)$ has proposed that the aminoglycoside-induced lethality might be a membrane event. It has been known for over 25 years that the release of $\mathrm{K}^{+}$is one of the earliest events after the addition of streptomycin to bacterial cells (Dubin \& Davis, 1962; Dubin et al., 1963; Hancock, 1964). Davis $(1987,1988)$ has proposed that the permeability changes caused by bactericidal aminoglycosides play an important role in the bactericidal action of these compounds. His hypothesis contains the following elements: (i) the insertion of aberrant proteins into the cell membrane causes an increase in the permeability of this membrane (see Hancock, 1964); (ii) the antibiotic can permeate through these 'channels', leading to enhanced streptomycin uptake (see Höltje, 1978, 1979); (iii) hence misreading increases and more channels are formed; and (iv) blockade of initiating ribosomes occurs. It is, however, controversial whether misreading (Gorini, 1974) or even protein synthesis (Stern et al., 1966) are necessary for streptomycin to cause lethality (Hancock, $1981 b$; Hausner et al., 1988). Moreover, the Davis mechanism does not explain why streptomycin uptake by cells is irreversible (Muir et al., 1984; Nichols \& Young, 1985; Nichols, 1989). Tanaka and coworkers have come forward with an alternative mechanism for the bactericidal action of aminoglycosides. They attribute habekacin-induced lethality to inhibition of the initiation of DNA replication due to the formation of an oriC-membrane complex being prevented (Tanaka et al., 1984; Matsunaga et al., 1986).

Because of the controversy about the relevance of misreading and membrane permeabilization for the bactericidal action of the aminoglycosides, we have reinvestigated the mechanism by which these compounds cause $\mathrm{K}^{+}$loss. In this communication we present evidence (i) that streptomycin causes permeability changes for other inorganic cations in addition to $\mathrm{K}^{+}$; (ii) that these permeability changes are sufficiently small that the treated cells still maintain a high membrane potential; (iii) that the increased membrane permeability occurs only under conditions where mistranslated proteins are present in the cell; (iv) that there exist conditions under which the cells degrade their mistranslated proteins rapidly; and (v) that this proteolysis might explain why streptomycin becomes 'caged' inside the cells. In the following paper it is shown that except for hygromycin B all the bactericidal aminoglycosides tested cause misreading and membrane permeabilization of the treated cells (Bakker, 1992).

\section{Methods}

Bacterial strains. The strains used are all derived from E. coli K12. Strains FRAG-1 (wild-type; Epstein \& Kim, 1971), FRAG-5 $\triangle k d p A B C 5$ (Epstein \& Kim, 1971), TK $1001 \triangle k d p A B C 5$ trkD1 (Rhoads et al., 1976), TK1110 $\triangle k d p A B C 5$ trkA405 (Rhoads et al., 1976), TK2240 nagA trkA405 trkD1 (Epstein et al., 1978) and TK2242 nagA $k d p 42$ trkA405 trkDl (Epstein et al., 1978) are all $\mathrm{F}^{-}$thi lacZ rha and were obtained from Dr W. Epstein, University of Chicago, Chicago, IL., USA. Strain AS-1 $\mathrm{F}^{-}$acrA (Imae, 1968) was from Dr Y. Imae, University of Nagoya, Japan.

Growth conditions. For most of the experiments cells were grown overnight at $37^{\circ} \mathrm{C}$ under aerobic conditions in a minimal medium containing $46 \mathrm{~mm}-\mathrm{Na}_{2} \mathrm{HPO}_{4}, 23 \mathrm{mM}-\mathrm{NaH}_{2} \mathrm{PO}_{4}, 8 \mathrm{~mm}-\left(\mathrm{NH}_{4}\right)_{2} \mathrm{SO}_{4}$,

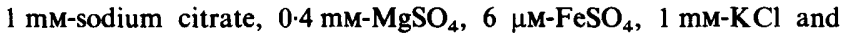
$10 \mathrm{~mm}$-glucose (Epstein \& Kim, 1971). When required, thiamin was also present, at $1 \mathrm{mg} \mathrm{l}^{-1}$. Next day the stationary-phase cells were diluted to an $\mathrm{OD}_{578}$ of about $\mathbf{0 . 1}$ in fresh growth medium in which the $\mathrm{KCl}$ concentration was reduced to $0.5 \mathrm{mM}$ (' $\mathrm{K} 0.5$ medium'). The minimal growth medium free of $\mathrm{Na}^{+}$contained 119 mM-choline chloride, $10 \mathrm{~mm}$-bistrispropane, $20 \mathrm{mM}-\left(\mathrm{NH}_{4}\right) \mathrm{H}_{2} \mathrm{PO}_{2}$ and the same $\mathrm{KCl}, \mathrm{FeSO}_{4}, \mathrm{MgSO}_{4}$, glucose and thiamin concentrations as the minimal medium described above (Giffard et al., 1985). Choline chloride was omitted from the medium that contained neither $\mathrm{Na}^{+}$nor choline.

Streptomycin treatment. The antibiotic was added to a concentration of $50 \mu \mathrm{g}$ per $\mathrm{ml}$ cell culture when the $\mathrm{OD}_{578}$ of the suspension had reached a value between $0 \cdot 7$ and $0 \cdot 8$. The $\mathrm{OD}_{578}$ of the suspension and the parameter of interest (e.g. cell $\mathrm{K}^{+}$content, cell viability) were then measured as a function of time both in control and in streptomycintreated cells.

Ion content, membrane potential and internal $\mathrm{pH}$. For these assays $1.0 \mathrm{ml}$ cell samples were taken at different time points and centrifuged through silicone oil (AR200 oil, relative density $\sim 1.04$; Wacker Chemie) in a Beckman B minicentrifuge (Bakker \& Mangerich, 1981). The $\mathrm{K}^{+}$and $\mathrm{Na}^{+}$content of the cell pellet were determined by flame photometry (Michels \& Bakker, 1987). The membrane potential of growing cells of strain AS-1 (Hirota et al., 1981) was determined with $\left[{ }^{14} \mathrm{C}\right] \mathrm{TPP}$ at a concentration of $20 \mathrm{nCi} \mathrm{ml}^{-1}\left(740 \mathrm{~Bq} \mathrm{ml}^{-1}\right)$ and a TPP chloride concentration of $1 \mu \mathrm{M}$. No correction was made for the binding of TPP to cellular components. Internal $\mathrm{pH}$ of the growing cells was determined with $\left[{ }^{14} \mathrm{C}\right]$ benzoic acid and ${ }^{3} \mathrm{H}_{2} \mathrm{O}$ (Kashket \& Barker, 1977) as described by (Dinnbier et al. (1988).

$\left[{ }^{3} \mathrm{H}\right]$ Dihydrostreptomycin transport. $\left[{ }^{3} \mathrm{H}\right]$ Dihydrostreptomycin uptake by washed cells and the efflux of the labelled compound from cells that had previously been loaded with the radioactively labelled antibiotic were determined as described by Nichols \& Young, 1985.

Viable cell count. Samples were taken from the cell cultures and diluted into buffer consisting of the sodium phosphates and $\mathrm{MgSO}_{4}$ of the minimal growth medium. The cells were then plated on $1.5 \%$ agar containing $\left(\mathrm{l}^{-1}\right): 10 \mathrm{~g}$ bactotryptone (Difco), $5 \mathrm{~g}$ yeast extract and $10 \mathrm{~g}$ $\mathrm{KCl}$. The concentration of viable cells for each sample was calculated from the number of colonies observed after overnight incubation of the plates at $37^{\circ} \mathrm{C}$.

Pulse-chase experiments with $\left[{ }^{35}\right.$ S $]$ methionine. These were done by labelling the proteins synthesized by $6 \mathrm{ml}$ of streptomycin-treated cells with $25-50 \mu \mathrm{Ci}$ of radioactivity (specific activity $\sim 1000 \mathrm{Ci} \mathrm{mmol}^{-1}$; $\sim 37 \mathrm{TBq} \mathrm{mmol}^{-1}$ ). After $2 \mathrm{~min}$ any further incorporation of radioactivity into proteins was stopped by the addition of either $10 \mu \mathrm{M}-\mathrm{L}-$ methionine or $10 \mu \mathrm{M}-\mathrm{L}$-methionine plus $100 \mu \mathrm{g}$ chloramphenicol ml-1. 
At different timepoints $1.0 \mathrm{ml}$ samples of the cell suspension were mixed with $0.1 \mathrm{ml} 50 \%(\mathrm{w} / \mathrm{v})$ trichloroacetic acid. The samples were transferred to $1.5 \mathrm{ml}$ microcentrifugation vials and incubated for $30 \mathrm{~min}$ at $4{ }^{\circ} \mathrm{C}$. The denatured protein was pelleted by centrifugation, and the sediments were washed twice with $1 \mathrm{ml} 10 \mathrm{mM}$-Tris/acetate, $0.1 \mathrm{~mm}$-phenylmethylsulphonyl fluoride $\mathrm{pH} 7.5$, followed each time by centrifugation. The pellets were solubilized in $0.1 \mathrm{ml}$ of electrophoresis sample buffer. After the sample had been boiled for $5 \mathrm{~min}$, the proteins were separated by SDS-PAGE on a gel prepared at $13 \%(w / v)$ acrylamide (Lugtenberg et al., 1975). Total and radioactively labelled proteins were visualized by staining with Coomassie blue and by autoradiography of the dried gel with Kodak XAR-5 X-ray film, respectively.

Materials. Streptomycin sulphate, dihydrostreptomycin sesquisulphate, spectinomycin dihydrochloride, tetracycline and puromycin were from Sigma. Hygromycin B was a gift from Professor Dr A. Böck, University of Munich, FRG. Chloramphenicol was from Serva. $\left[{ }^{3} \mathrm{H}\right]$ Dihydrostreptomycin sesquisulphate $\left(18.3 \mathrm{Ci} \mathrm{g}^{-1} ; 677 \mathrm{GBq} \mathrm{g}^{-1}\right)$, tetra[ $\left[{ }^{14} \mathrm{C}\right.$ phenylphosphonium bromide $\left(31.4 \mathrm{Ci} \mathrm{mol}^{-1} ; 1.16 \mathrm{TBq}\right.$ $\mathrm{mol}^{-1}$ ), ${ }^{35}$ S]methionine (about $1000 \mathrm{Ci} \mathrm{mmol}^{-1}$; about $37 \mathrm{TBq}$ mmol $\left.{ }^{-1}\right),{ }^{3} \mathrm{H}_{2} \mathrm{O}$ and ${ }^{86} \mathrm{Rb}^{+}$were from Amersham-Buchler. [ $\left.{ }^{14} \mathrm{C}\right]$ Benzoic acid $\left(19 \cdot 3 \mathrm{Ci} \mathrm{mol}^{-1} ; 714 \mathrm{GBq} \mathrm{mol}^{-1}\right)$ was from Dupont-NEN.

\section{Results}

\section{$\mathrm{K}^{+}$efflux from $\mathrm{K}^{+}$-uptake mutants}

Dubin et al. (1963) showed that the streptomycininduced loss of $\mathrm{K}^{+}$from cells is an early event that slightly precedes lethality. These authors also presented evidence that $\mathrm{K}^{+}$loss is due to a stimulation of $\mathrm{K}^{+}$efflux rather than to an inhibition of $\mathrm{K}^{+}$uptake. Their experiments were, however, not carried out under welldefined conditions, since they were done at the low concentration of added $\mathrm{K}^{+}$of $0.1 \mathrm{~mm}$ and during the course of the experiment the cells may have taken up as much as $80 \%$ of the added $\mathrm{K}^{+}$. Moreover, it is now known that at low $\mathrm{K}^{+}{ }_{\text {out }} E$. coli derepresses the high- affinity $\mathrm{K}^{+}$-uptake system, $\mathrm{Kdp}$ (for a review see Walderhaug et al., 1987). The derepression of $\mathrm{Kdp}$ during the experiment may also have influenced the result.

Since 1963 mutants have been described that are impaired in $\mathrm{K}^{+}$transport via the different $\mathrm{K}^{+}$-uptake systems (Table 1). These systems are the inducible highaffinity Kdp system (see above), the constitutive highrate systems TrkG and TrkH, and the constitutive lowrate system Kup, which is the gene product of the trkD gene (Rhoads et al., 1976; Bossemeyer et al., 1989a, $b$; Dosch et al., 1991). We tested the effect of $50 \mu \mathrm{g}$ streptomycin $\mathrm{ml}^{-1}$ on the $\mathrm{K}^{+}$content of $\mathrm{K}^{+}$-uptake mutants growing at $0.5 \mathrm{mM}-\mathrm{K}^{+}$. This $\mathrm{K}^{+}$concentration is sufficiently high that all the mutants still grew with similar rates, which enabled us to make a direct comparison of the effect of the antibiotic on the different strains (Fig. 1a). Moreover, at $0.5 \mathrm{~mm}-\mathrm{K}^{+}$the external $\mathrm{K}^{+}$concentration decreased by only $30 \%$ during cell growth, which should not have influenced the level of $k d p$ expression during the experiment to a great extent.

Fig. 1 (a) shows that the less well the cells are able to pump $\mathrm{K}^{+}$, the faster was the onset of $\mathrm{K}^{+}$efflux caused by streptomycin. Thus, with cells that are wild-type for $\mathrm{K}^{+}$uptake systems (strain FRAG-1 and presumably strain AS-1; Table 1) it took about $20 \mathrm{~min}$ before streptomycin exerted any effect (open diamonds and open circles, respectively). For cells lacking functional Trk systems or lacking $\mathrm{Kdp}$ this time lag decreased to $15 \mathrm{~min}$ [strains FRAG-5 ( $\triangle k d p A B C)$ and TK2240 (trkA trkD); open and filled squares, respectively]. The time lag was reduced to less than $10 \mathrm{~min}$ for cells that lacked functional Kdp and Kup systems (strain TK1001, filled circles). A lag time of approximately $5 \mathrm{~min}$ was observed for TK2242, which only contains a Kdp system with a reduced affinity for $\mathrm{K}^{+}$uptake (Epstein et al., 1978; Fig. 1 , open triangles). The fastest onset of $\mathrm{K}^{+}$loss was

Table 1. $K^{+}$-uptake systems in $E$. coli and their properties

\begin{tabular}{|c|c|c|c|c|c|}
\hline \multirow[b]{2}{*}{ System } & \multirow{2}{*}{$\begin{array}{l}\text { Mode of } \\
\text { expression }\end{array}$} & \multicolumn{2}{|c|}{$\begin{array}{l}\mathbf{K}^{+} \text {-transport } \\
\text { parameters } \ddagger\end{array}$} & \multirow{2}{*}{$\begin{array}{c}\mathbf{K}^{+} / \mathbf{R b}^{+} \\
\text {specificity } \dagger\end{array}$} & \multirow{2}{*}{$\begin{array}{l}\text { Strain(s) in which } \\
\text { system present } \ddagger\end{array}$} \\
\hline & & $K_{\mathrm{m}} \S$ & $V_{\max } \S$ & & \\
\hline Kdp & Derepressible & 0.002 & $50-150$ & $\geqslant 1000$ & FRAG-1, TK2240, AS-1\| \\
\hline $\mathrm{Kdp}^{*}$ & Derepressible & $\sim 1$ & $50-150$ & ND & TK2242 \\
\hline TrkG, TrkH & Constitutive & $\sim 1$ & $200-500$ & $\sim 10$ & FRAG-5, TK 1001, AS-1\| \\
\hline Kup & Constitutive & $\sim 0.5$ & $30-50$ & $\sim 1$ & FRAG-5, TK 1110, AS-1\| \\
\hline
\end{tabular}

ND, Not determined.

* $\mathrm{Kdp}^{*}$ is a $\mathrm{Kdp}$ system with reduced affinity for $\mathrm{K}^{+}$uptake (Epstein et al., 1978).

$\dagger$ Data from Rhoads et al. (1977), Bakker (1983), Bossemeyer et al. (1989a)

‡ Data from Rhoads et al. (1976), Epstein et al. (1978), Dosch et al. (1991).

$\S K_{\mathrm{m}}$ in $\mathrm{mM}, V_{\max }$ in $\mathrm{nmol} \mathrm{min}^{-1}$ (mg cell dry $\left.\mathrm{wt}\right)^{-1}$.

$\|$ It is not known which $\mathrm{K}^{+}$-uptake systems are made by strain AS-1. 


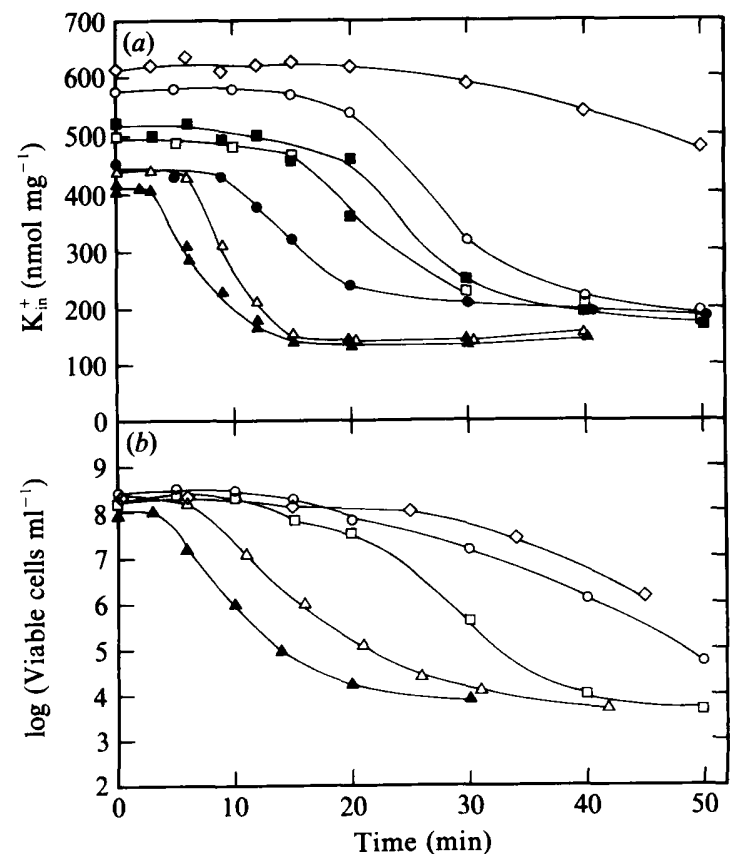

Fig. 1. $\mathrm{K}^{+}$efflux $(a)$ and loss of viability $(b)$ of $\mathrm{K}^{+}$uptake mutants treated with streptomycin. At zero time the antibiotic was added at a concentration of $50 \mu \mathrm{g} \mathrm{ml}^{-1}$ to cells growing in $\mathrm{K} 0.5$ medium. The $\mathrm{K}^{+}$ content of the cells and the number of viable cells $\mathrm{ml}^{-1}$ were determined as a function of time as described in Methods. $\diamond$, Strain

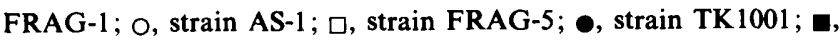
strain TK2240; $\Delta$, strain TK2242; $\Delta$, strain TK1110.

observed with strain TK1110 (filled triangles), which possesses a functional Kup system only. Strain TK1110 was employed for most of the experiments described below.

Fig. $1(b)$ shows that poorly $\mathrm{K}^{+}$-pumping cells also started to lose their viability earlier. Below we will argue that these differential effects of the antibiotic on cells with different $\mathrm{K}^{+}$-uptake systems may be due to faster uptake of the antibiotic by poorly $\mathrm{K}^{+}$-pumping cells.

The effects depicted in Fig. 1 did not occur in cells of an $r p s L$ strain, in which protein synthesis is insensitive to streptomycin (results not shown; cf. the results of Hancock, 1964, with Bacillus cereus), indicating that $\mathrm{K}^{+}$ efflux from the cells is not the result of a direct interaction of the antibiotic with the cytoplasmic membrane.

\section{${ }^{86} R b^{+}-R b^{+}$exchange}

The Kup system transports $\mathrm{K}^{+}$and $\mathrm{Rb}^{+}$with similar rates and affinities (Bossemeyer et al., 1989b). Thus, we were able to use ${ }^{86} \mathrm{Rb}^{+}$to mimic $\mathrm{K}^{+}$transport in strain TK 1110. Streptomycin caused $\mathbf{R b}^{+}$loss from $\mathbf{R b}^{+}$-loaded cells with a time course almost identical to that of $\mathrm{K}^{+}$loss

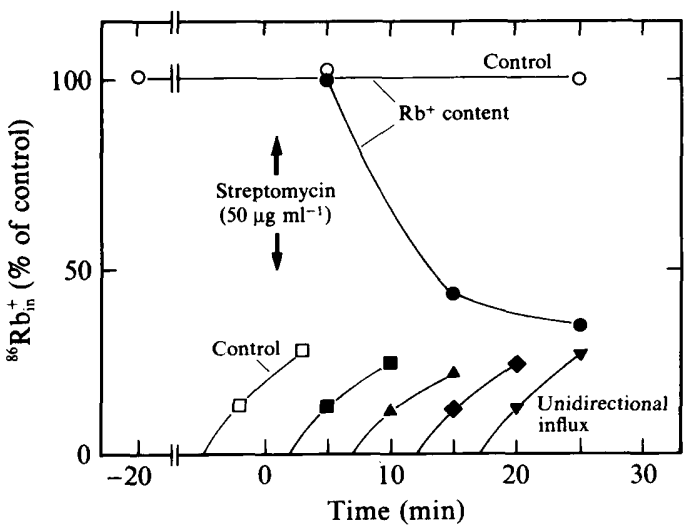

Fig. 2 Streptomycin specifically stimulates $\mathbf{R b}^{+}$efflux from cells growing at low $\mathrm{K}^{+}\left(\mathbf{R b}^{+}\right)$concentrations. Cells of strain TK1110 were grown in three identical portions in $\mathrm{K} 0.5$ medium. At $t=-120 \mathrm{~min}$ two cultures received $0.1 \mathrm{mM}-\mathrm{RbCl}$ and $20 \mathrm{nCi}^{86} \mathrm{Rb}^{+} \mathrm{ml}^{-1}(0, \bullet)$. At zero time $50 \mu \mathrm{g}$ of streptomycin $\mathrm{ml}^{-1}$ was added to one of these cultures (•). The third culture received at $t=-120 \mathrm{~min}$ only $0 \cdot 1 \mathrm{mM}-\mathrm{RbCl}$ and at zero time $50 \mu \mathrm{g}$ of streptomycin $\mathrm{ml}^{-1}$. From this culture $5 \mathrm{ml}$ of cells were transferred to Erlenmeyer flasks at different timepoints and incubated with $20 \mathrm{nCi}^{86} \mathrm{Rb}^{+} \mathrm{ml}^{-1}(\square, \mathbf{a}, \Delta, \bullet, \nabla)$. The ${ }^{80} \mathrm{Rb}^{+}$content of the cells was determined as a function of time. The $100 \%$ value of the ${ }^{86} \mathrm{Rb}^{+}$content of the cells amounts to about $80 \mathrm{nmol}(\mathrm{mg} \text { dry } \mathrm{wt})^{-1}$ ( $55 \mathrm{~mm})$.

(not shown). The unidirectional influx of the isotope remained the same during the period that the cells lost net $\mathbf{R b}^{+}$(Fig. 2). Hence, streptomycin stimulates $\mathbf{R b}^{+}$ $\left(\mathrm{K}^{+}\right)$efflux rather than inhibiting the influx of these cations. The same conclusion was drawn by Dubin et al. (1963).

\section{At high $K_{\text {out }}^{+}$streptomycin increases the $K^{+}$content of the cells}

At increasing external $\mathrm{K}^{+}$concentrations the time lag between the addition of the antibiotic and its effects on cell $\mathrm{K}^{+}$content and cell viability increased (Fig. 3). Moreover, at 30 or $115 \mathrm{mM}-\mathrm{K}^{+}$the antibiotic caused net uptake instead of net loss of $\mathrm{K}^{+}$(Fig. $3 a$ ), indicating that the antibiotic increases the passive permeability of the cell membrane to $\mathrm{K}^{+}$. The retardation of the action of streptomycin by high $\mathrm{K}^{+}$may be due to a slower uptake of the antibiotic by $\mathrm{K}^{+}$-replete than by $\mathrm{K}^{+}$-depleted cells (see below).

Even under conditions at which streptomycin caused net $\mathrm{K}^{+}$uptake the drug was bactericidal (Fig. 3, open and filled squares). Moreover, addition of $10 \mathrm{mM}-\mathrm{K}^{+}$to cells previously treated with streptomycin at $0.5 \mathrm{~mm}-\mathrm{K}^{+}$led to reaccumulation of $\mathrm{K}^{+}$, but did not retard the rate with which the cells lost their viability (Fig. 4). Thus, loss of $\mathrm{K}^{+}$is not a prerequisite for the bactericidal action of streptomycin. 


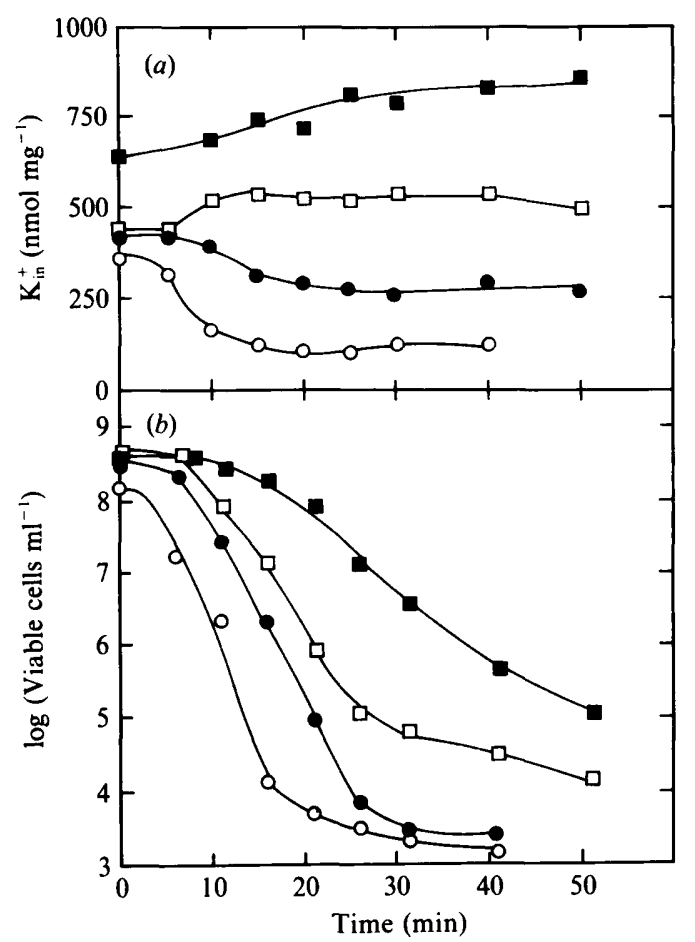

Fig. 3. $\mathrm{K}^{+}$content $(a)$ and viability $(b)$ of cells treated with streptomycin at different $\mathrm{K}^{+}$concentrations. Cells of $E$. coli TK 1110 were grown at the following $\mathrm{K}^{+}$concentrations: $0.5 \mathrm{~mm}(\mathrm{O}) ; 10 \mathrm{mM}$ $(\bullet) ; 30 \mathrm{~mm}(\square)$ and $115 \mathrm{~mm}(\square)$. Streptomycin $\left(50 \mu \mathrm{g} \mathrm{ml}^{-1}\right)$ was added at zero time. The $\mathrm{K}^{+}$content of the cells and number of viable cells of the suspension were determined as a function of time.

\section{Permeability changes for other ions}

Under the conditions where the cells lost $\mathrm{K}^{+}$, they took up $20 \%$ more $\mathrm{Na}^{+}$than they lost $\mathrm{K}^{+}$(Fig. $5 a$ ). Thus, streptomycin not only affects the transmembrane concentration gradient of $\mathrm{K}^{+}$and $\mathrm{Rb}^{+}$, but also that of another inorganic cation. In the experiment of Fig. 5(a), part of the $\mathrm{Na}^{+}$taken up in excess of $\mathrm{K}^{+}$was electrically compensated for by the efflux of $\mathrm{H}^{+}$, since the internal $\mathrm{pH}$ of the cells increased by $0 \cdot 15$ units (Fig. $5 b$ ). Sodium was not required for $\mathrm{K}^{+}$loss, since streptomycin-treated cells grown in the absence of $\mathrm{Na}^{+}$lost $\mathrm{K}^{+}$with a time course and to an extent similar to those of cells grown in the presence of $\mathrm{Na}^{+}$(Fig. $5 c, e$ ). Cells grown in the absence of $\mathrm{Na}^{+}$did not exchange $\mathrm{K}^{+}$for $\mathrm{H}^{+}$after streptomycin treatment, since the internal $\mathrm{pH}$ of these cells increased rather than decreased (Fig. 5d) This indicates that under these conditions the uptake of unidentified cations (possibly choline) or the exit of unidentified anions accompanies $\mathrm{K}^{+}$loss. Omission of choline and $\mathrm{Na}^{+}$from the medium led to a slightly different behaviour: $\mathrm{K}^{+}$loss became transient (Fig. 5e) and the internal $\mathrm{pH}$ of the treated cells was only initially

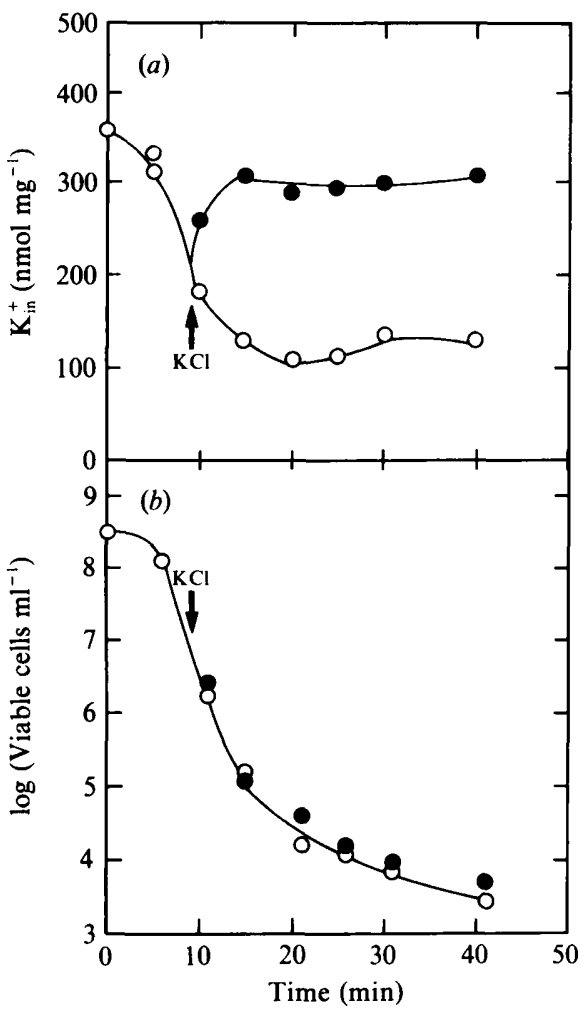

Fig. 4. The addition of an excess of $\mathrm{K}^{+}$to cells treated with streptomycin reverses $\mathrm{K}^{+}$loss $(a)$ but does not affect the rate with which cells lose their viability $(b)$. Two cultures of $E$. coli TK 1110 were grown in $\mathrm{K0} .5$ medium. At zero time $50 \mu \mathrm{g}$ streptomycin $\mathrm{ml}^{-1}$ was added to the two cell suspensions. At $t=9 \mathrm{~min}$ one culture received $10 \mathrm{mM}-\mathrm{KCl}(\bullet)$. The second culture served as the control (O). The $\mathrm{K}^{+}$ content of the cells and the number of viable cells were determined as a function of time.

higher than that of control cells (Fig. $5 f$ ). We will return to the phenomenon of transient $\mathrm{K}^{+}$loss below.

\section{Membrane potential}

The effects of streptomycin on cell membrane permeability are not large since streptomycin-treated cells still maintained substantial concentration gradients of $\mathrm{K}^{+}\left(\mathrm{Rb}^{+}\right)$and $\mathrm{H}^{+}$across their cytoplasmic membranes (Figs 1-5). To obtain more information on this point we measured the membrane potential of cells of strain AS-1, in which this potential can be measured without pretreatment with EDTA (Hirota et al., 1981). Remarkably, streptomycin caused hyperpolarization during the period that the cells lost $\mathrm{K}^{+}$(Fig. 6). This effect may be partially due to the inhibition of protein synthesis by streptomycin since chloramphenicol, added at a concentration at which it blocks protein synthesis completely, caused an even larger hyperpolarization (Fig. 6a). This 


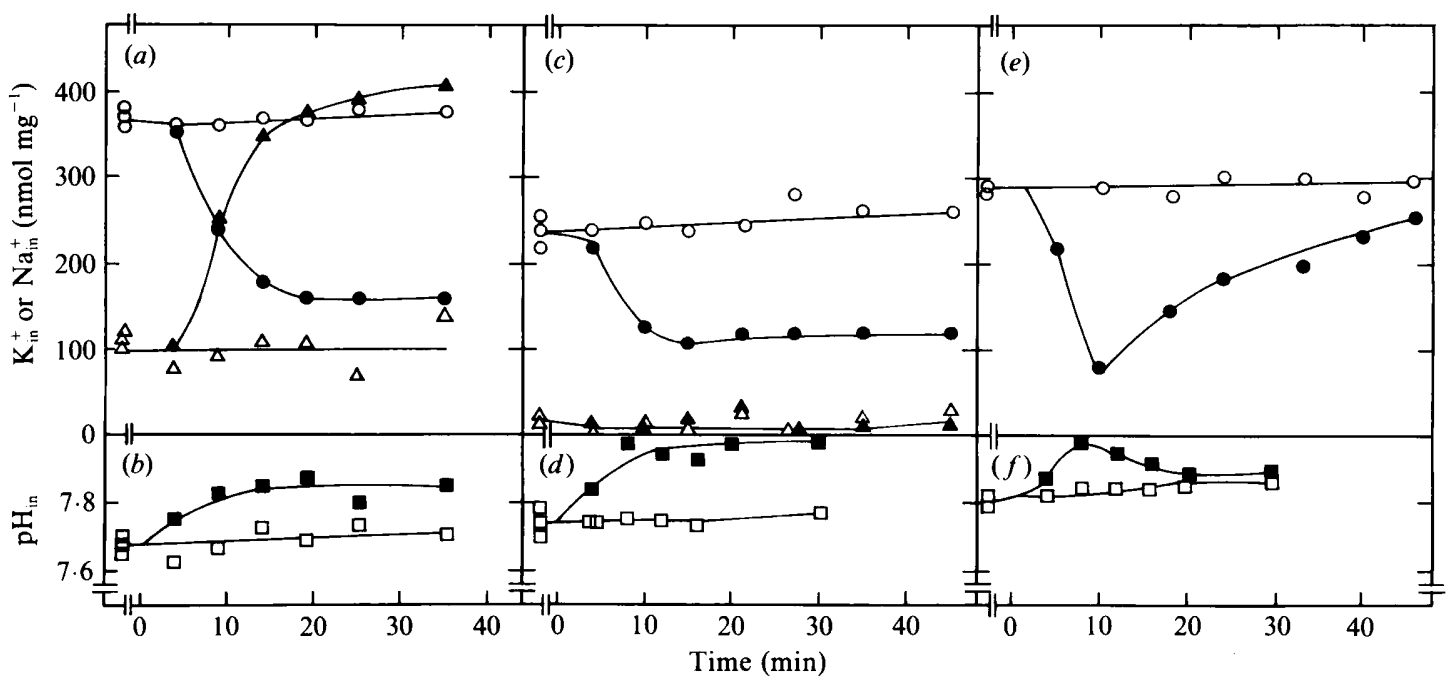

Fig. 5. $\mathrm{K}^{+}$and $\mathrm{Na}^{+}$content and internal $\mathrm{pH}$ of streptomycin-treated cells grown in media of different composition. E. coli TK 1110 cells were grown in $\mathrm{K} 0.5$ medium, which contains $115 \mathrm{mM}^{-} \mathrm{Na}^{+}(a, b)$, in medium without $\mathrm{Na}^{+}(c, d)$ or in medium without $\mathrm{Na}^{+}$and choline

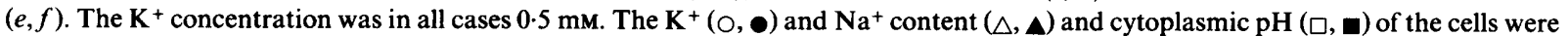
determined as a function of time. Open symbols, control cells; filled symbols, cells treated with $50 \mu \mathrm{g}$ streptomycin ml ${ }^{-1}$ at zero time.

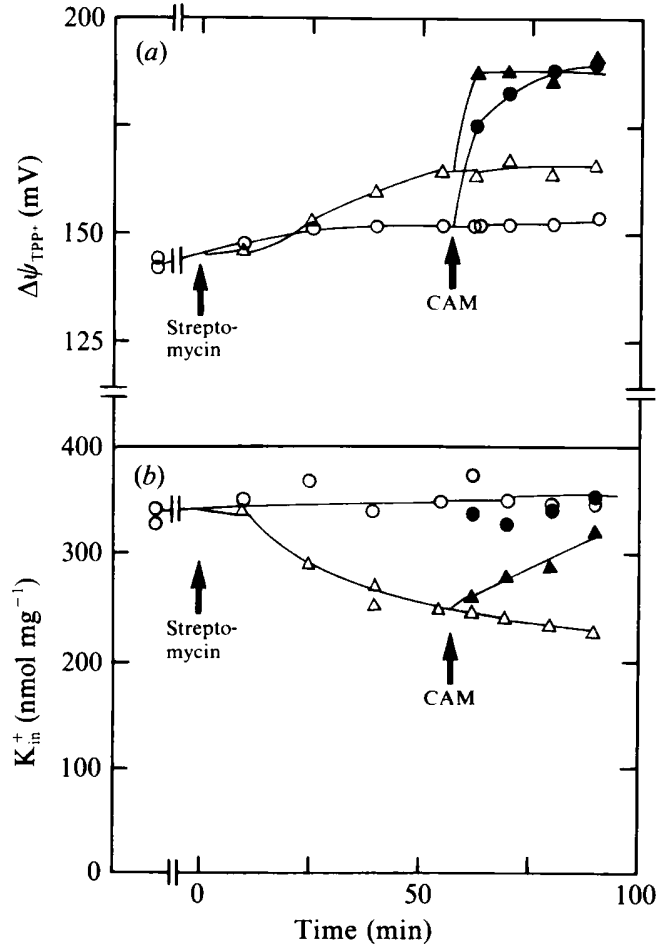

Fig. 6. Membrane potential (a) and $\mathrm{K}^{+}$content $(b)$ of streptomycintreated cells of $E$. coli strain AS-1. $\left[{ }^{14} \mathrm{C}\right] \mathrm{TPP}$ chloride $(1 \mu \mathrm{M}, 20 \mathrm{nCi}$ $\mathrm{ml}^{-1}$ ) was added at $t=30$ min to cells growing in $\mathrm{K} 0.5$ medium. $O$, Control cells; $\bullet$, control cells to which $100 \mu \mathrm{g}$ chloramphenicol (CAM) $\mathrm{ml}^{-1}$ was added at $t=57 \mathrm{~min} . \triangle$, Cells that were treated with $50 \mu \mathrm{g}$ streptomycin $\mathrm{ml}^{-1}$ at zero time; $\Delta$, streptomycin-treated cells that also received $100 \mu \mathrm{g}$ chloramphenicol $\mathrm{ml}^{-1}$ at $t=57 \mathrm{~min}$. hyperpolarization is probably the result of the decreased ATP demand of cells in which protein synthesis is inhibited.

Addition of $100 \mathrm{~mm}-\mathrm{K}^{+}$to streptomycin-treated cells depolarized the cells only partially (not shown). Together with the results of Figs 1-6 this result indicates that streptomycin increases the permeability of the cell membrane for more ions than $\mathrm{K}^{+}$alone, and that these effects are small, and balance each other in such a way that the membrane potential remains high. The actual value of the membrane potential of streptomycin-treated cells will be determined both by the extent of the permeability changes and by the decreased energy demand of the cells due to inhibition of protein synthesis.

\section{Reversal of permeabilization by a second inhibitor of protein synthesis}

Figs $6(a)$ and 7 show that the addition of $100 \mu \mathrm{g}$ chloramphenicol $\mathrm{ml}^{-1}$ reversed $\mathrm{K}^{+}$loss from cells previously treated with streptomycin. Under these conditions chloramphenicol prevents further loss of viability of streptomycin-treated cells, but does not reverse it (Plotz \& Davis, 1961). The addition of $50 \mu \mathrm{g}$ hygromycin $\mathrm{B}$ or spectinomycin $\mathrm{ml}^{-1}$ also reversed $\mathrm{K}^{+}$ loss from streptomycin-treated cells. Other inhibitors of protein synthesis were less effective in this process: tetracycline $\left(15 \mu \mathrm{g} \mathrm{ml}^{-1}\right)$ reversed $\mathrm{K}^{+}$loss, but with a slower rate than did chloramphenicol. Puromycin $\left(200 \mu \mathrm{g} \mathrm{ml}^{-1}\right)$ merely prevented further $\mathrm{K}^{+}$efflux (results not shown). 


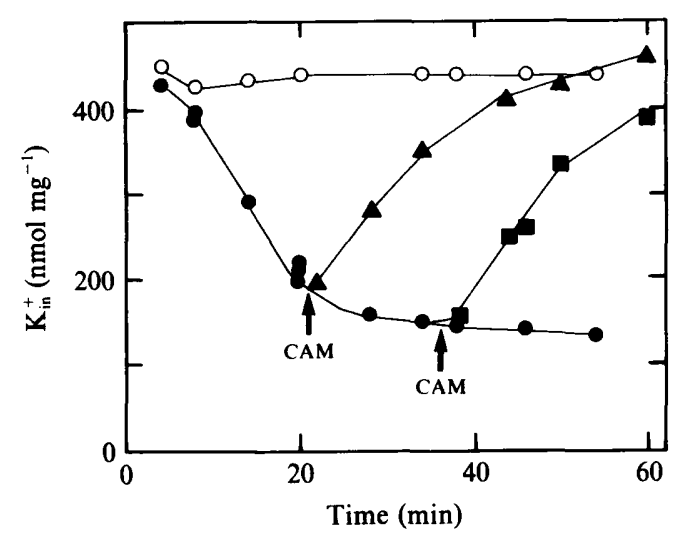

Fig. 7: Reversal of $\mathrm{K}^{+}$loss from streptomycin-treated cells by chloramphenicol. Four cultures of cells of strain TK 1110 were grown in $\mathrm{K} 0.5$ medium. One culture (O) served as a control. Streptomycin $(50 \mu \mathrm{g}$ $\mathrm{ml}^{-1}$ ) was added to the other three cultures at zero time. To two of these cultures $100 \mu \mathrm{g}$ chloramphenicol $(\mathrm{CAM}) \mathrm{ml}^{-1}$ was added at $t=21(\Lambda)$ and $t=36 \mathrm{~min}(\square)$. The fourth culture did not receive any further addition ( $\bullet$ ). The $\mathrm{K}^{+}$content of the cells was determined as a function of time.

\section{Reaccumulation of $\mathrm{K}^{+}$due to degradation of mistranslated proteins}

The streptomycin-induced permeability changes of the cell membrane may arise from mistranslated proteins present in this membrane (Hancock, 1964; Davis, 1987). If this hypothesis is correct, one would expect that streptomycin-treated cells that reaccumulate $\mathrm{K}^{+}$(Figs $5 e, 6$ and 7) have degraded their mistranslated proteins. Fig. 8 shows that this is indeed the situation. In this experiment streptomycin-treated cells were pulselabelled with $\left[{ }^{35}\right.$ S $]$ methionine. The autoradiogram of the synthesized proteins separated by SDS-PAGE showed diffuse bands (Fig. 8, lanes 1 and 7), due to the errors in protein synthesis (Piepersberg, 1985; Davis et al., 1986; Bakker, 1992). During a subsequent chase with an excess of non-radioactive methionine plus chloramphenicol the labelled proteins were degraded during the time that the cells reaccumulated $\mathrm{K}^{+}$(Fig. 8, lanes 2-6). Under these conditions cell proteins synthesized before streptomycin addition were stable (results not shown), indicating that only the mistranslated proteins were hydrolysed. A control experiment in which chloramphenicol was omitted during the chase showed neither degradation of mistranslated proteins nor reaccumulation of $\mathrm{K}^{+}$(Fig. 8, lanes 7-12). Cells growing in the medium without $\mathrm{Na}^{+}$ and choline (i.e. the conditions of Fig. $5 e, f$ ) also degraded the proteins synthesized after the addition of streptomycin (not shown). Thus, reversal of $\mathrm{K}^{+}$efflux appears to be due to enhanced rate of proteolysis of the mistranslated proteins.

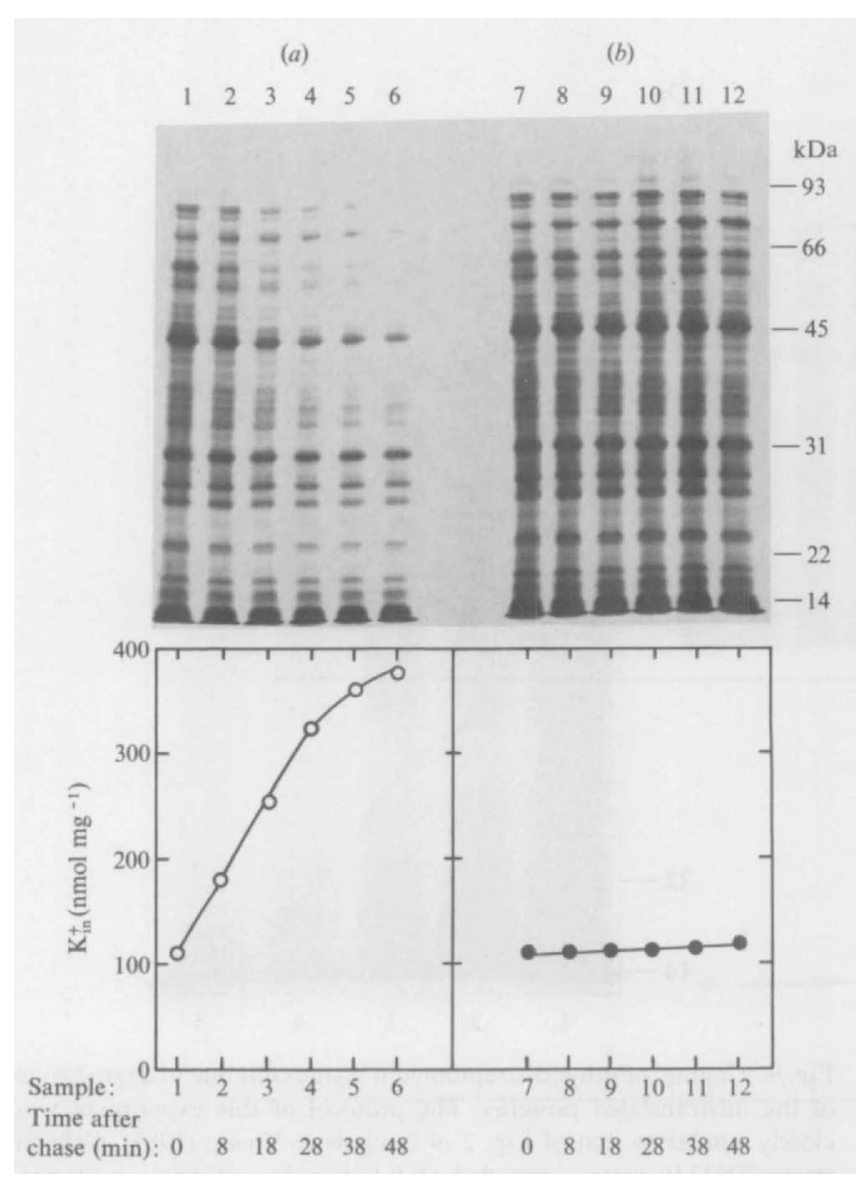

Fig. 8. Chloramphenicol induces proteolysis of the aberrant proteins synthesized by streptomycin-treated cells. Two cultures of TK 1110 cells were grown in $\mathrm{K} 0.5$ medium. At $t=-9 \mathrm{~min}$ both cultures received $50 \mu \mathrm{g}$ streptomycin $\mathrm{ml}^{-1}$. To $6 \mathrm{ml}$ of each culture $25 \mu \mathrm{Ci}\left[{ }^{35}\right.$ S]methionine $\left(1000 \mathrm{Ci} / \mathrm{mmol}^{-1}\right)$ was added at zero time. Culture $(a)$ received at $t=2 \mathrm{~min} 10^{-5} \mathrm{M}$-methionine plus $100 \mu \mathrm{g}$ chloramphenicol $\mathrm{ml}^{-1}$ ('chase'). Culture (b) was 'chased' with $10^{-5} \mathrm{M}$-methionine alone. At various timepoints cells were denatured with trichloroacetic acid and the pattern of radioactively labelled proteins was determined as described in Methods (upper part of the figure). In a parallel experiment the $\mathrm{K}^{+}$content of the cells was determined at the different timepoints after the 'chase' (lower part).

\section{The irreversibility of (dihydro)streptomycin uptake}

We confirmed the results of Nichols \& Young (1985) that dihydrostreptomycin uptake is irreversible. Moreover, even when cells were washed free of external antibiotic and were subsequently completely depolarized by the addition of $5 \mathrm{~mm}$ of the protonophore 2,4dinitrophenol, they did not lose their previously accumulated dihydrostreptomycin (not shown, cf. Fig. 2 of Nichols \& Young, 1985). We then argued that the 


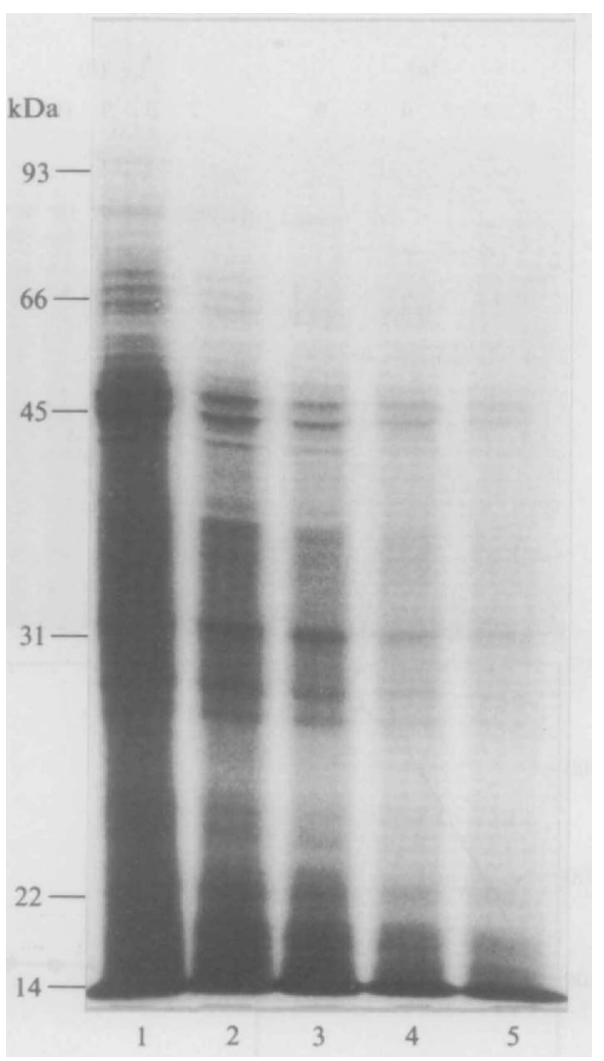

Fig. 9. 'Caging' of dihydrostreptomycin inside cells due to degradation of the mistranslated proteins. The protocol of this experiment was closely similar to that of Fig. 2 of Nichols \& Young (1985). Cells of strain TK 1110 were suspended at $0.18 \mathrm{mg}$ dry wt $\mathrm{ml}^{-1}$ in $50 \mathrm{~mm}$ sodium HEPES, pH 7.0. The suspension was shaken at $37^{\circ} \mathrm{C}$. At zero time $10 \mathrm{~mm}$-glucose and $15 \mu \mathrm{g}$ dihydrostreptomycin $\mathrm{ml}^{-1}$ were added to the suspension. At $t=15 \mathrm{~min} 10 \mathrm{ml}$ of this suspension was labelled with $25 \mu \mathrm{Ci}$ [ ${ }^{35}$ S]methionine. At $t=20 \mathrm{~min}$ any further incorporation of radioactivity into protein was prevented by the addition of $10^{-5} \mathrm{M}$ methionine. Lane 1 represents the pattern of radioactively labelled proteins from $1 \mathrm{ml}$ of cells taken immediately after the latter addition. The remainder of the suspension was shaken for $120 \mathrm{~min}$. Lanes 2 and 3 show the pattern of radioactively labelled proteins from $1 \mathrm{ml}$ of cell samples taken after 50 and $90 \mathrm{~min}$ of shaking, respectively. After 120 min the remaining cells were collected by centrifugation, and washed free of external antibiotic and methionine by two subsequent centrifugations. The cells were then suspended in $5 \mathrm{ml}$ of the sodium HEPES/glucose buffer described above and again shaken at $37^{\circ} \mathrm{C}$. Lanes 4 and 5 show the pattern of radioactively labelled proteins from $1 \mathrm{ml}$ of cells taken immediately after resuspension in buffer and after 20 min of shaking, respectively.

irreversibility of streptomycin uptake might also be due to rapid degradation of the mistranslated proteins. Fig. 9 shows that under the conditions used by Nichols \& Young (1985) for their experiments the aberrant proteins that were synthesized after dihydrostreptomycin addition were indeed degraded during the subsequent incubation and washing procedure.

\section{Discussion}

The data presented in the first part of this paper indicate that treatment with streptomycin increases the passive permeability of the $E$. coli cell membrane to several small ions (Figs 1-6). The changes in these permeabilities are relatively small and the membrane potential of the treated cells remains high (Fig. 6). Our data therefore argue against the notion that streptomycin treatment leads to formation of transmembrane channels (Davis, 1987) in the sense of aqueous pores, since the presence of such channels would increase the permeability of the cell membrane to one or more ions by several orders of magnitude.

Due to the increase of the passive $\mathrm{K}^{+}$permeability of the cell membrane, the transmembrane $\mathrm{K}^{+}$gradient of the treated cells will have a stronger tendency to equilibrate with the high membrane potential. Thus at low $\mathrm{K}_{\text {out }}^{+}$(i.e. at $\left.61.5 \log \left(\left[\mathrm{K}^{+}\right]_{\text {in }} /\left[\mathrm{K}^{+}\right]_{\text {out }}\right) \geqslant \Delta \psi\right)$ the treated cells will lose some of their $\mathrm{K}^{+}$(Figs 1-8), whereas at high $\mathrm{K}_{\text {out }}^{+}$(i.e. at $\left.61.5 \log \left(\left[\mathrm{K}^{+}\right]_{\text {in }} /\left[\mathrm{K}^{+}\right]_{\text {out }}\right) \leqslant \Delta \psi\right)$ the treated cells will take up some additional $\mathrm{K}^{+}$(Figs 3 and 4 ).

Streptomycin-induced lethality was not prevented by high $\mathrm{K}_{\text {out }}^{+}$(Figs 3 and 4), indicating that lethality is not the consequence of net $\mathrm{K}^{+}$loss from the cells. This situation is different from that of lethality caused by membrane-active bacteriocins. These compounds form channels in the cell membrane (for a review see Cramer et al., 1983) and lethality is at least partly due to the complete loss of $\mathrm{K}^{+}$via the channel, since plating of colicin A-treated cells at high $\mathrm{K}_{\text {out }}^{+}$leads to survival of the cells (Kopecky et al., 1975).

The inverse correlation observed between the onset of streptomycin action and the ability of the cells to pump $\mathrm{K}^{+}$(Fig. 1a) may be related to the $\mathrm{K}^{+}$content of the cells and their membrane potentials: cells that pump $\mathrm{K}^{+}$ poorly at $0.5 \mathrm{~mm}-\mathrm{K}^{+}$contained relatively little $\mathrm{K}^{+}$(Fig. 1a). $\mathrm{K}^{+}$-depleted cells develop higher membrane potentials than do $\mathrm{K}^{+}$-replete cells (Kashket \& Barker, 1977; Bakker \& Mangerich, 1981; Kroll \& Booth, 1981). Since the rate at which the polycation streptomycin is taken up by the cells is a steep function of the membrane potential (Damper \& Epstein, 1981 ; Bryan \& Kwan, 1983; Emling \& Höltje, 1987), $\mathrm{K}^{+}$-depleted cells will take up streptomycin faster and will be affected by the antibiotic earlier (Figs 1 and 3). Hence, our data indirectly support the notion that the magnitude of the membrane potential determines the rate at which streptomycin is taken up by the cells (Damper \& Epstein, 1981; Bryan \& Kwan, 1983; Taber et al., 1987; Emling \& Höltje, 1987).

Different groups have reported different effects of some antibiotics on the membrane potential of $E$. coli or Bacillus subtilis: gentamicin depolarizes $B$. subtilis 
(Bryan \& Kwan, 1983) and E. coli (our unpublished results); by contrast, streptomycin hyperpolarizes these bacteria (Emling \& Höltje, 1987; Fig. 6 of this study); in addition, chloramphenicol depolarizes $B$. subtilis (Emling \& Höltje, 1987), but hyperpolarizes E. coli (Fig. 6).. It is difficult to compare these results with each other, since (i) two organisms were treated with different antibiotics; (ii) the media in which the cells were suspended and the temperature were different; (iii) different probes were used to monitor the membrane potential [i.e. TPP ${ }^{+}$by Bryan \& Kwan (1983) and by us, and TPMP ${ }^{+}$in the presence of a small concentration of tetraphenylboron by Emling \& Höltje (1987)]; and (iv) the concentration of the probe was different. The latter point is important, since both $E$. coli and $B$. subtilis possess an efflux system for lipophilic cations like TPP ${ }^{+}$ and $\mathrm{TPMP}^{+}$(e.g. Midgley, 1986; Bakker, 1990). The activity of this system disturbs membrane potential measurements at low probe concentrations (Midgley, 1986; Bakker, 1990). On the other hand, high concentrations of $\mathrm{TPP}^{+}$or $\mathrm{TPMP}^{+}$inhibit many cellular processes (e.g. Bakker, 1990). Thus, results on bacterial membrane potentials obtained with lipophilic cations like TPP+ have to be taken with extreme caution. Nevertheless, the following conclusions can be drawn: (i) gentamicin and streptomycin have opposite effects on the membrane potential (Bryan \& Kwan, 1983; Emling \& Höltje, 1987; Fig. 6, and our unpublished observations); (ii) hyperpolarization alone cannot be the cause of the acceleration of (dihydro)streptomycin uptake known as 'EDPII phase' (e.g. Höltje, 1979; Bryan \& Kwan, 1983), since (a) chloramphenicol hyperpolarizes $E$. coli cells (Fig. 6), but inhibits (dihydro)streptomycin uptake, and (b) gentamicin depolarizes bacterial cells (Bryan \& Kwan, 1983), but stimulates (dihydro)streptomycin uptake (Allen et al., 1987.). In addition, our data do not support the notion that the phenomena of $\mathrm{K}^{+}$efflux and the phase of enhanced (dihydro)streptomycin uptake ('EDPII') are directly related to each other. First, the extent of $\mathrm{K}^{+}$ release is orders of magnitudes larger than that of streptomycin uptake, and second, and more importantly, during $\mathrm{K}^{+}$release the cells take up more than an equivalent amount of $\mathrm{Na}^{+}$ions (Fig. $5 a$ ). Rather, all of these data can be explained satisfactorily by - but do not prove - the hypothesis that aminoglycoside treatment leads to the insertion of aberrant proteins into the membrane of the treated bacteria (Davis, 1987), causing some permeabilization, the extent of which varies with the antibiotic used. Permeabilization then leads to $\mathrm{K}^{+}$ efflux, stimulation of uptake of aminoglycosides and $\mathrm{Na}^{+}$, and differential effects on the membrane potential.

Our data not only support but also extend the hypothesis of Davis (1987) about how streptomycin exerts lethality. First, we observed a correlation between the presence of mistranslated proteins in the cell and the increase in the cell membrane permeability (Fig. 8), lending support to the notion that these permeability changes are the consequence of the presence of mistranslated proteins in this membrane (Hancock, 1964; Davis et al., 1986; Davis, 1987). Secondly, the result that streptomycin-treated cells often degrade the mistranslated proteins rapidly (Figs 5, 7-9) may shed some light on the hitherto unexplained observation that streptomycin uptake by the cells is irreversible (Muir et al., 1984; Nichols \& Young, 1985; Nichols, 1989). Under the conditions used for measuring efflux of the antibiotic the cells had already degraded the majority of their aberrant proteins (Fig. 9). Thus, the excess of antibiotic that had been taken up by the cells during the period that the cells were permeabilized became 'caged' inside the cytoplasm. Moreover, the driving force for streptomycin efflux by de-energized cells is small, being a function of the cell membrane permeability multiplied by the concentration difference of the antibiotic across this membrane. By contrast, the driving force for uptake of the drug by energized cells is much larger, being a steep function of the membrane potential (Damper \& Epstein, 1981; Bryan \& Kwan, 1983; Emling \& Höltje, 1987). Thus, it can be explained why cells in which membrane tightness has been restored lose streptomycin extremely slowly under conditions where the same cells when energized would still take up the antibiotic slowly. Thirdly, 'caged' antibiotic will cause prolonged inhibition of protein synthesis and may prevent colony formation in plating experiments (Davis, 1987, 1988).

Although we consider the hypothesis of Davis (1987) as reasonably satisfactory, we cannot exclude the pessibility that lethality caused by streptomycin is due to a different, hitherto unknown effect of the antibiotic. It is.for instance possible that misreading affects a cellular process in such a way that a vital process like cell division or DNA replication becomes impaired. In fact, evidence has already been presented that lethal aminoglycosides that do cause misreading also inhibit the initiation of DNA replication in a temperature-sensitive $d n a C$ strain (Tanaka et al., 1984; Matsunaga et al., 1986; Bakker, 1992).

Finally, it is not clear why enhanced protease activity occurs only under the conditions of the experiments of Figs 5(e, $f), 7$ and 8 (lanes 1-6). Nevertheless, these results extend the observation that treatment with streptomycin increases the protease activity of the treated cells (Hipkiss \& Kogut, 1973). In the following paper it is proposed that streptomycin treatment may initiate the general stress response of the cells (Bakker, 1992). Thus, conditions like those in the experiments of Fig. 5(e,f), or Figs 7 and 8 may stimulate the activity of the proteases among the stress proteins. 
This work was supported by grants from the Deutsche Forschungsgemeinschaft, SFB 171, project $\mathrm{Cl}$, from the Fonds der Chemischen Industrie, and from the European Community, contract SC-1-0334C(A). We thank Eva Limpinsel for expert technical assistance, $J$. Lengeler for drawing our attention to streptomycin, and A. Böck and W. Piepersberg for helpful discussion.

\section{References}

Allen, N. E., Alborn, W. E., Kirst, H. A. \& Toth, J. E. (1987). Comparison of aminoglycoside antibiotics with respect to uptake and lethal activity in Escherichia coli. Journal of Medical Chemistry 30, 333-340.

ANDRY, K. \& BOCKRATH, R. C. (1974). Dihydrostreptomycin accumulation in $E$. coli. Nature, London 251, 534-536.

BAKKER, E. P. (1983). pH-dependent transport of rubidium by the constitutive potassium uptake system TrkA of Escherichia coli. FEMS Microbiology Letters 16, 229-233.

BAKKeR, E. P. (1990). The role of alkali-cation transport in energy coupling of neutrophilic and acidophilic bacteria: an assessment of methods and concepts. FEMS Microbiology Reviews 75, 319-334.

BAKKER, E. P. (1992). Aminoglycoside and aminocyclitol antibiotics: hygromycin $B$ is an atypical bactericidal compound that exerts effects on cells of Escherichia coli characteristic for bacteriostatic aminocyclitols. Journal of General Microbiology 138, 563-569.

BAKKeR, E. P. \& MANGerich, W. E. (1981). Interconversion of components of the bacterial proton motive force by electrogenic potassium transport. Journal of Bacteriology 147, 820-826.

Bossemeyer, D., Schlösser, A. \& BaKKer, E. P. (1989a). Specific cesium transport via the Escherichia coli Kup (TrkD) $\mathrm{K}^{+}$uptake system. Journal of Bacteriology 171, 2219-2221.

Bossemeyer, D., Borchard, A., Dosch, D. C., Helmer, G. C., EPSTEIN, W., BoOTh, I. R. \& BAKKeR, E. P. $(1989 b)$. K+-transport protein TrkA of Escherichia coli is a peripheral membrane protein that requires other trk gene products for attachment to the cytoplasmic membrane. Journal of Biological Chemistry 264, 1640316410 .

BRIMACOMBE, R. (1988). The emerging three-dimensional structure and function of 16S ribosomal RNA. Biochemistry 27, 4207-4214.

BRYAN, L. E. \& KWAN, S. (1983). Roles of ribosomal binding, membrane potential, and electron transport in bacterial uptake of streptomycin and gentamicin. Antimicrobial Agents and Chemotherapy 23, 835-843.

Chang, F. N. \& Flaks, J. G. (1972). Binding of dihydrostreptomycin to Escherichia coli coli ribosomes: characteristics and equilibrium of the reaction. Antimicrobial Agents and Chemotherapy 2, 294-307.

Cramer, W. A., Dankert, J. R. \& URATANI, Y. (1983). The membrane channel-forming bactericidal protein colicin E1. Biochimica et Biophysica Acta 737, 173-193.

DAMPER, P. D. \& EPSTEIN, W. (1981). Role of the membrane potential in bacterial resistance to aminoglycoside antibiotics. Antimicrobial Agents and Chemotherapy 20, 803-808.

DAvis, B. D. (1987). Mechanism of bactericidal action of aminoglycosides. Microbiological Reviews 51, 341-350.

DAvis, B. D. (1988). The lethal action of aminoglycosides. Journal of Antimicrobial Chemotherapy 22, 1-3.

DAVIS, B. D., ChEN, L. \& TAI, P. C. (1986). Misread protein creates membrane channnels: an essential step in the bactericidal action of aminoglycosides. Proceedings of the National Acadamy of Sciences of the United States of America 83, 6164-6168.

Davis, B. D., TAI, P. C. \& Wallace, B. J. (1974). Complex interactions of antibiotics with the ribosome. In Ribosomes, pp. 771-789. Edited by M. Nomura, A. Tissieres \& P. Lengyel. Cold Spring Harbor, NY: Cold Spring Harbor Laboratory.

Dinndier, U., Limpinsel, E., SChMid, R. \& BaKker, E. P. (1988). Transient accumulation of potassium glutamate and its replacement by trehalose during adaptation of growing cells of Escherichia coli K12 to elevated sodium chloride concentrations. Archives of Microbiology 150, 348-357.
Dosch, D. C., Helmer, G. L., Sutton, S. H., Salvacion, F. F. \& EPstern, W. (1991). Genetic analysis of potassium transport loci in Escherchia coli: evidence for three constitutive systems mediating uptake of potassium. Journal of Bacteriology 173, 687-696.

Dubin, D. T. \& Davis, B. D. (1961). The effect of streptomycin on potassium flux in Escherichia coli. Biochimica et Biophysica Acta 52, 400-402.

Dubin, D. T., Hancock, R. \& Davis, B. D. (1963). The sequence of events of some effects of streptomycin in Escherichia coli. Biochimica et Biophysica Acta 74, 476-489.

EMLING, F. \& HöLTJE, J.-V. (1987). Autostimulation of dihydrostreptomycin uptake in Bacillus subtilis. Journal of General Microbiology 133, 3495-3504.

EPSTEIN, W. \& KIM, B. S. (1971). Potassium loci in Escherichia coli. Journal of Bacteriology 108, 639-644.

Epstern, W., WhitelaW, V. \& Hesse, J. (1978). A $\mathrm{K}^{+}$transport ATPase in Escherichia coli. Journal of Biological Chemistry 253, 66666668.

Giffard, P. M., Rowland, G. C., Kroll, R. H., Stewart, L. M. D., BAKKeR, E. P. \& BooTH, I. R. (1985). Phenotypic properties of a unique rpoA mutation (phs) of Escherichia coli. Journal of Bacteriology $164,904-910$.

GORINI, L. (1974). Streptomycin and misreading of the genetic code. In Ribosomes, pp. 791-803. Edited by M. Nomura, A. Tissieres \& P. Lengyel. Cold Spring Harbor, NY: Cold Spring Harbor Laboratory.

HANCOCK, R. (1964). Early effects of streptomycin on Bacillus megaterium. Journal of Bacteriology 88, 633-639.

HANCOCK, R. E. W. (1981a). Aminoglycoside uptake and mode of action - with special reference to streptomycin and gentamicin. I. Antagonists and mutants. Journal of Antimicrobial Chemotherapy 8, 249-276.

HANCOCK, R. E. W. $(1981 b)$. Aminoglycoside uptake and mode of action - with special reference to streptomycin and gentamicin. II. Effects of aminoglycosides on cells. Journal of Antimicrobial Chemotherapy 8, 429-445.

Hausner, T.-P., Geigenmüller, U. \& Nierhaus, K. H. (1988). The allosteric three-site model for the ribosome elongation cycle. New insights into the inhibition mechanisms of aminoglycosides, thiostrepton, and viomycin. Journal of Biological Chemistry 263, 1310313111.

HIPKISS, A. R. \& KOGUT, M. (1973). Stimulation of protein breakdown in Escherichia coli by dihydrostreptomycin. Transactions of the Biochemical Society 1, 594-596.

Hirota, N., Matsuura, S., Mochizuki, N., Mutoh, N. \& Imae, Y. (1981). Use of lipophilic cation-permeable mutants for measurement of transmembrane electrical potential in metabolizing cells of Escherichia coli. Journal of Bacteriology 148, 399-405.

HöLTJE, J.-V. (1978). Streptomycin uptake via inducible polyamine transport system in Escherichia coli. European Journal of Biochemistry 86, 345-351.

HöLTJE, J.-V. (1979). Induction of streptomycin uptake in resistant strains of Escherichia coli. Antimicrobial Agents and Chemotherapy 15, $177-181$.

IMAE, Y. (1968). Mitomycin C-sensitive mutant of Escherichia coli K-12. Journal of Bacteriology 95, 1191-1192.

KASHKET, E. R. \& BARKER, S. L. (1977). Effect of potassium ions on the electrical and $\mathrm{pH}$ gradients across the membrane of Streptococcus lactis cells. Journal of Bacteriology 130, 1017-1023.

KoPeCKY, A. L., COPELAND, D. P. \& LUSK, J. E. (1975). Viability of Escherichia coli treated with colicin K. Proceedings of the National Academy of Sciences of the United States of America 72, 46314634.

KROLL, R. G. \& BOOTH, I. R. (1981). The role of potassium transport in the generation of a pH gradient in Escherichia coli. Biochemical Journal 198, 691-698.

Lugtenberg, B., Meijers, J., Peters, R., van der Hoek, P. \& van ALPHEN, L. (1975). Electrophoretic resolution of the major outer membrane protein of Escherichia coli K-12 into four bands. FEBS Letters 58, 254-258.

Matsunaga, K., Yamaki, H. Nishimura, T. \& Tanaka, N. (1986). Inhibition of DNA replication initiation by aminoglycoside antibiotics. Antimicrobial Agents and Chemotherapy 30, 468-474. 
MiChels, M. \& BAKKER, E. P. (1987). Low affinity potassium uptake system in Bacillus acidocaldarius. Journal of Bacteriology 169, 43424348.

MidGLEY, M. (1986). The phosphonium ion efflux system of Escherichia coli: relationship to the ethidium efflux system and energetic studies. Journal of General Microbiology 132, 3187-3193.

MUIR, M. E., VAN HeESWYCK, R. S. \& Wallace, R. J. (1984). Effect of growth rate on streptomycin accumulation by Escherichia coli and Bacillus megaterium. Journal of General Microbiology 130, 2015-2022.

Nichols, W. W. (1989). The enigma of streptomycin transport. Journal of Antimicrobial Chemotherapy 22, 673-676.

Nichols, W. W. \& Young, S. N. (1985). Respiration-dependent uptake of dihydrostreptomycin by Escherichia coli. Its irreversible nature and lack of evidence for a uniport mechanism. Biochemical Journal 228, 505-512.

Nierhaus, K. H. \& Wittmann, H. G. (1980). Ribosomal function and its inhibition by antibiotics in prokaryotes. Naturwissenschaften $\mathbf{6 7}$, 234-250.

PIePERSBerg, W. (1985). Aminoglycosid-Antibiotika: Wichtige Therapeutika und Objekte der Grundlagenforschung. Forum Mikrobiologie 8, 153-161.

Plotz, P. H. \& Davis, B. R. (1961). Absence of a chloramphenicolinsensitive phase of streptomycin action. Journal of Bacteriology 83 , 802-805.
RHOADS, D. B., WATERS, F. B. \& EPSTEIN, W. (1976). Cation transport in Escherichia coli. VIII. Potassium transport mutants. Journal of General Physiology 67, 325-341.

RhoAds, D. B., Woo, A. \& Epstein, W. (1977). Discrimination between $\mathrm{Rb}^{+}$and $\mathrm{K}^{+}$by Escherichia coli. Biochimica et Biophysica Acta 469, 45-51.

Stern, J. L., Barner, H. D. \& Cohen, S. S. (1966). The lethality of streptomycin and the stimulation of RNA synthesis in the absence of protein synthesis. Journal of Molecular Biology 17, 188-217.

Taber, H. W., Mueller, J. H., Miller, P. F. \& Arrow, A. S. (1987). Bacterial uptake of aminoglycoside antibiotics. Microbiological Reviews 51, 439-457.

Tanaka, N., Matsunaga, K., Yamaki, H. \& Nishimura, T. (1984). Inhibition of initiation of DNA synthesis by aminoglycoside antibiotics. Biochemical and Biophysical Research Communications $122,460-465$.

Walderhaug, M. O., Dosch, D. C. \& Epstein, W. (1987). Potassium transport in bacteria. In Ion Transport in Prokaryotes, pp. 84-130. Edited by B. P. Rosen \& S. Silver. New York: Academic Press.

WittmanN, H. G. (1989). Ribosomen und Proteinbiosynthese. Biological Chemistry Hoppe Seyler 370, 87-99. 